\title{
A study on use of blended ferrocement: a high performance material for repair/strengthening of brick masonry columns
}

\author{
T. Kibriya \\ National University of Sciences and Technology, Risalpur, Pakistan
}

\begin{abstract}
The use of ferrocement, containing blended cement, to repair and enhance the strength of brick masonry columns of old buildings and structures showing distress has been investigated for use as a rehabilitation/strengthening material. Intensive experimental study has been carried out on plain brick masonry columns and brick masonry columns with single, double and triple layers of ferrocement, with/without the use of chemical bonding agents. Use of blended cements containing agricultural waste i.e. rice husk ash have not as yet been investigated at all for use in ferrocement. Blended cement containing 75\% OPC and $25 \%$ rice husk ash has now been investigated for use in ferrocement.

Ferrocement containing blended cement has been observed to substantially increase the load carrying capacity of brick masonry columns along with decreasing the strains by about $50 \%$. Strength improvements of up to $160 \%$ in the load carrying capacity of columns with single layered ferrocement have been observed whilst about $100 \%$ strength improvements have been observed in columns with $2 / 3$ layers of ferrocement applications. The slope of the stress-strain curve resembles typical curves characteristic of high strengths. The results of this study have been highly encouraging and the use of ferrocement with blended cement is recommended for the repair and rehabilitation/strengthening of brick masonry columns. The use of rice husk ash for blending with ordinary Portland cement produces a stronger, impermeable and durable material in addition to ease of in-situ application, reducing the disposal problem of this agricultural waste and reducing the costs of repairs. Keywords: strengthening, rehabilitation, brick masonry columns, blended cement, old buildings, retrofit material.
\end{abstract}




\section{Introduction}

Many old buildings along with few bearing historical architecture of past civilisations were constructed by using brick masonry. Most of these old buildings/structures have shown signs of distress/damage due to aging and action of various offensive agencies. To maintain the safety requirements, most such structures now require replacement/ rehabilitation/ strengthening. Strengthening of existing columns may also be required for expansion works in the existing buildings/structures. With the trend of conserving the heritage and specific architecture/ façade along with avoiding environmental/disposal problems of demolition waste, stress is laid on rehabilitation/ strengthening of the existing elevations/structures. Resource conservation and paucity of development funds in developing/under developed countries suggests economical options of rehabilitation/ strengthening of existing structures. To maintain economy and environment, use of waste materials in concrete have been investigated widely. Lot of work has been done on use of waste brick aggregates (widely available from old dilapidated buildings in the South Asian region) in normal/high strength concrete by Kibriya [1-4] and use of agricultural waste in blended cement and normal/high strength concrete Kibriya [5-8]. Ferrocement carries certain advantages in rehabilitation/strengthening works like in-situ application, ease of construction, use of locally available materials, no formworks, no special skills/training required, easily moulded in any shape, very low permeability, easily repairable, resource saving and durability vide Kibriya [9, 10], Paul and Pama [11], ACI [12] and BOSTID [13]. The repair and strengthening of existing structures has been a more challenging problem for civil engineers than construction of new structures.

Use of blended cements containing agricultural waste i.e. rice husk ash have not at all been investigated as yet for use in ferrocement. Higher content of silica found in rice husk ashes along with low calcium oxide content is advantageous as far as its cementing properties are concerned. Blended cements containing rice husk ash as a partial replacement material have been found to improve strength and durability characteristics substantially when used as cementitious material and in high strength concretes for various purposes. Blended cement containing $75 \%$ OPC and $25 \%$ rice husk ash has now been investigated for use in ferrocement. Selection of $25 \%$ replacement of OPC with rice husk ash has been on the basis of excellent performance of such blended cements and concrete in the recent studies by Kibriya [5-8].

\section{Research methodology}

This experimental investigation was carried out on nine different groups of columns. Each group consisted of three specimen $225 \times 225 \times 750 \mathrm{~mm}$. The groups were labeled in alphabetical order and the individual specimens were thus numbered as 1, 2 and 3 and so on. $1^{\text {st }}$ Group i.e Group A comprised of plain brick masonry in 1:4 cement mortar and were considered as control specimen. Group B comprised of brick masonry columns in 1:4 cement mortar with 
12.5mm thick, 1:4 cement mortar plaster. Group $\mathrm{C}$ were brick masonry columns in 1:4 cement mortar, simply plastered with 1:2 cement mortar. Groups D, E and F comprised of brick masonry columns in 1:4 cement mortar with one, two and three layers of ferrocement applied respectively. Each layer of ferrocement applied was $15 \mathrm{~mm}$ thick applied in two steps i.e. a layer of $7 \mathrm{~mm} \mathrm{1:2} \mathrm{cement}$ mortar, application of wire mesh and another $8 \mathrm{~mm}$ layer of 1:2 cement mortar. $\mathrm{W} / \mathrm{C}$ ratio of mortar was maintained at 0.3 . Blended cement containing $25 \%$ rice husk ash and $75 \%$ ordinary Portland cement was used. Rice husk ash used for blending was obtained by burning rice husk in an industrial furnace with temperatures maintained around 500 to $600^{\circ} \mathrm{C}$. Ashes were then cooled to $20^{\circ} \mathrm{C}$ and subsequently ground in a laboratory ball mill for about 120 minutes and thereafter sieved through a \#325 sieve. Ashes passing 100\% through the sieve were then used for blending with ordinary Portland cement. Sand with medium grading was used for mortar. Upto $1 \%$ high range water reducing admixture was used for preparing workable mortar mix. Wire mesh of expanded metal having openings of $15 \mathrm{~mm}$ and wire thickness of $1 \mathrm{~mm}$ was applied with yield strength of $227 \mathrm{~N} / \mathrm{mm}^{2}$ and ultimate strength of $379 \mathrm{~N} / \mathrm{mm}^{2}$. $1 \mathrm{~mm}$ thick, $2.5 \mathrm{~cm}$ long nails were used to bind wire mesh layers to the core. Groups $\mathrm{G}, \mathrm{H}$, and I comprised of specimen similar to groups $\mathrm{D}, \mathrm{E}$ and $\mathrm{F}$ with the exception that a chemical bonding agent Sika-Latex was used in addition to nails to bind the ferrocement layer to the core. The specimen were moist cured for 28 days at a temperature around $20^{\circ} \mathrm{C}$ before testing. The details are shown in Table 1.

\section{Testing procedure}

The column specimen were tested for compression using universal compression testing machine with a $255 \times 255 \mathrm{~mm}, 5 \mathrm{~mm}$ thick plate on top and bottom. The observations were made for stress-strain behavior, crack pattern, cracking and failure loads. The measurements for strain were done with the help of two compressometers attached to the specimen. The results of the tests are tabulated in Table 2. Permeability testing was carried out by the help of capillary rise test according to RILEM CPC13 and Initial Surface Absorption (ISAT) tests according to BS 1881 . In addition, $50 \mathrm{mmx} 50 \mathrm{~mm}$ cubes were caste, moist cured for 30 days and immersed in water for 30 days to observe any weight changes.

\section{Analysis of test results}

The ultimate failure and cracking load capacities of the specimen are given in Table 2. The stress-strain curves and trend lines based on the average readings of the specimen groups are shown in Figures 1 and 2.

\subsection{Brick masonry columns (group A)}

The failure loads were generally identical. The average failure load for case A was $142 \mathrm{kN}$. The crack initiation started at about $70 \%$ of the failure loads. Major cracks were vertically oriented, however, a few horizontal cracks were also 
observed. The crack widening and propagation was quite fast after their first appearance. The stress - strain behaviour of this group is shown in Figs 1and 2.

Table 1: Details of specimen.

\begin{tabular}{|l|l|l|l|l|}
\hline Type of Specimen & $\begin{array}{l}\text { Group } \\
\text { Designation }\end{array}$ & $\begin{array}{l}\text { No of } \\
\text { Layers }\end{array}$ & $\begin{array}{l}\text { Bonding } \\
\text { Agent }\end{array}$ & $\begin{array}{l}\text { Mortar } \\
\text { Ratio }\end{array}$ \\
\hline Masonry Col & A & - & - & - \\
\hline $\begin{array}{l}\text { Masonry Col With } \\
\text { Plaster }\end{array}$ & B & - & - & $1: 4$ \\
\hline $\begin{array}{l}\text { Masonry Col with } \\
\text { Plaster }\end{array}$ & C & - & - & $1: 2$ \\
\hline $\begin{array}{l}\text { Masonry Col + } \\
\text { Ferro cement }\end{array}$ & D & 1 & Nails & $1: 2$ \\
\hline $\begin{array}{l}\text { Masonry Col + } \\
\text { Ferro cement }\end{array}$ & E & 2 & Nails & $1: 2$ \\
\hline $\begin{array}{l}\text { Masonry Col + } \\
\text { Ferro cement }\end{array}$ & F & 3 & Nails & $1: 2$ \\
\hline $\begin{array}{l}\text { Masonry Col + } \\
\text { Ferro cement }\end{array}$ & G & 1 & $\begin{array}{l}\text { Nails \& } \\
\text { S. Latex }\end{array}$ & $1: 2$ \\
\hline $\begin{array}{l}\text { Masonry Col + } \\
\text { Ferro cement }\end{array}$ & H & 2 & $\begin{array}{l}\text { Nails \& } \\
\text { S .Latex }\end{array}$ & $1: 2$ \\
\hline $\begin{array}{l}\text { Masonry Col + } \\
\text { Ferro cement }\end{array}$ & I & 3 & $\begin{array}{l}\text { Nails \& } \\
\text { S. Latex }\end{array}$ & $1: 2$ \\
\hline
\end{tabular}

Note:-

- Brick Masonry in 1:4 Cement Mortar.

- One layer of ferrocement mortar $15 \mathrm{~mm}$ thick with 1:2 cement mortar.

- Wire mesh with $1 \mathrm{~mm}$ wire, $15 \mathrm{~mm}$ mesh.

- Cementitious material - 75\% OPC $+25 \%$ Rice Husk Ash

- $\mathrm{W} / \mathrm{C}$ ratio 0.3 of ferrocement.

- $\quad$ Moist curing - 28 days

\subsection{Brick masonry columns with 1:5 cement mortar plaster (group B)}

The results of all specimen of group B clearly suggest that simple mortar application can increase the failure loads by up to $35 \%$. However, it seems to have no effect on crack initiation and it's growth as the crack growth was rapid as in case of group A. The cracks generally started at about $70 \%$ of failure load. The average failure load was $195 \mathrm{kN}$ as given in Table 2 . The strains also reduced somewhat, as compared to plain brick masonry columns as shown in Figure 1.

\subsection{Brick masonry columns with 1:2 cement mortar plaster (group C)}

The specimen of group C exhibited fairly good results in terms of failure loads. The average failure load was calculated as $208 \mathrm{kN}$. This clearly shows an increase of about $46 \%$ over the failure load of the control specimen of Case A 
and about $10 \%$ increase over columns plastered with 1:5 mortar ratio. The stressstrain curve is fairly straight with reduced strains as shown in Figure 2.

Table 2: $\quad$ Summary of test results.

\begin{tabular}{|c|c|c|c|c|c|}
\hline Type of Specimen & Group & $\begin{array}{l}\text { First } \\
\text { cracking } \\
\text { Load }(\mathrm{kN})\end{array}$ & $\begin{array}{l}\text { Failure } \\
\text { Load } \\
(\mathrm{kN})\end{array}$ & $\begin{array}{l}\text { Mean } \\
\text { Failure } \\
\text { Load }(\mathrm{kN})\end{array}$ & $\begin{array}{l}\% \\
\text { Increase }\end{array}$ \\
\hline Masonry Col & $\mathrm{A}$ & $\begin{array}{l}86.19 \\
113.00 \\
104.10 \\
\end{array}$ & $\begin{array}{l}138.4 \\
141.2 \\
146.8 \\
\end{array}$ & 142.13 & Control \\
\hline $\begin{array}{ll}\text { Masonry } & \text { Col } \\
\text { With Plaster } & \end{array}$ & B & $\begin{array}{l}146.40 \\
124.60 \\
157.10\end{array}$ & $\begin{array}{l}192.1 \\
198.3 \\
196.4\end{array}$ & 195.6 & 37.6 \\
\hline $\begin{array}{l}\text { Masonry Col with } \\
\text { Plaster }\end{array}$ & $\mathrm{C}$ & $\begin{array}{l}142.00 \\
128.00 \\
146.60\end{array}$ & $\begin{array}{l}211.1 \\
208.4 \\
204.7\end{array}$ & 208.1 & 46.5 \\
\hline $\begin{array}{l}\text { Masonry Col }+ \\
\text { Ferro cement } \\
\text { (1 Layer) }\end{array}$ & $\mathrm{D}$ & $\begin{array}{l}187.30 \\
196.30 \\
212.20\end{array}$ & $\begin{array}{l}340.9 \\
394.2 \\
367.2 \\
\end{array}$ & 367.4 & 158.7 \\
\hline $\begin{array}{l}\text { Masonry Col }+ \\
\text { Ferro cement } \\
(2 \text { Layers })\end{array}$ & $E$ & $\begin{array}{l}157.30 \\
186.00 \\
175.80 \\
\end{array}$ & $\begin{array}{l}299.4 \\
268.6 \\
279.5 \\
\end{array}$ & 282.5 & 98.9 \\
\hline $\begin{array}{l}\text { Masonry Col }+ \\
\text { Ferro cement } \\
(3 \text { Layers })\end{array}$ & $\mathrm{F}$ & $\begin{array}{l}202.10 \\
195.80 \\
186.40 \\
\end{array}$ & $\begin{array}{l}310.4 \\
301.5 \\
270.8 \\
\end{array}$ & 294.3 & 107.3 \\
\hline $\begin{array}{l}\text { Masonry Col + } \\
\text { Ferrocement(1) } \\
\text { Bonding Agent }\end{array}$ & $\mathrm{G}$ & $\begin{array}{l}204.70 \\
192.10 \\
224.20\end{array}$ & $\begin{array}{l}354.8 \\
396.2 \\
377.1\end{array}$ & 376 & 164.8 \\
\hline $\begin{array}{l}\text { Masonry Col + } \\
\text { Ferrocement(2) } \\
\text { Bonding Agent }\end{array}$ & $\mathrm{H}$ & $\begin{array}{l}162.50 \\
197.60 \\
166.26 \\
\end{array}$ & $\begin{array}{l}280.4 \\
359.7 \\
260.9 \\
\end{array}$ & 300.3 & 111.5 \\
\hline $\begin{array}{l}\text { Masonry Col + } \\
\text { Ferro cement(3) } \\
\text { Bonding Agent }\end{array}$ & $\mathrm{I}$ & $\begin{array}{l}142.90 \\
189.70 \\
178.80\end{array}$ & $\begin{array}{l}281.7 \\
320.1 \\
318.4 \\
\end{array}$ & 306.7 & 116 \\
\hline
\end{tabular}

\subsection{Brick masonry columns with single layer of ferrocement (group D)}

The specimen of this group having one layer of ferrocement showed a marked difference in results by increasing the failure load to $367 \mathrm{kN}$, an increase of $158 \%$ over the control. The crack propagation was not rapid and widening of cracks occurred gradually thus showing a ductile failure. The increased failure load and mode of failure clearly suggests usefulness of ferrocement in strength enhancement of brick masonry columns. Failure strains were observed to be around $60 \%$ of the strains in the control. 


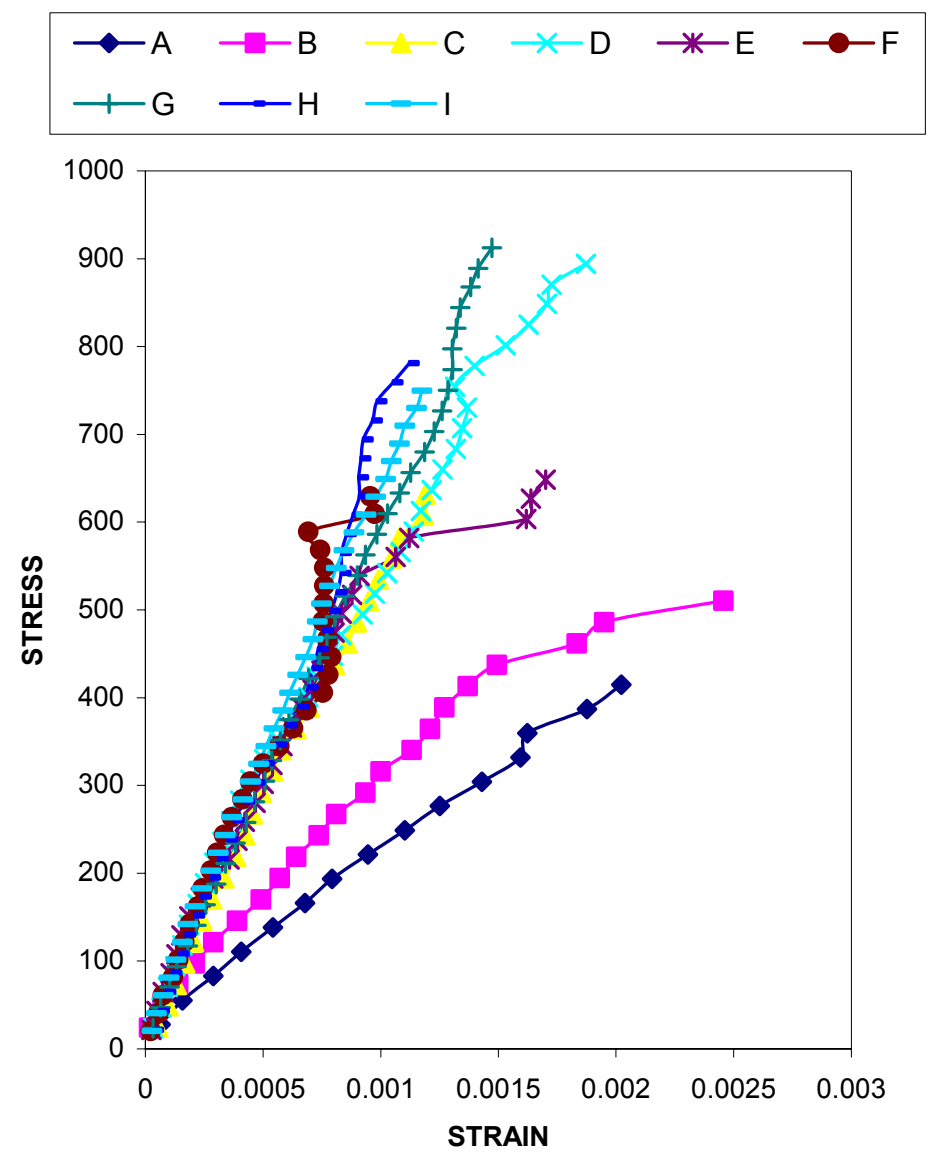

Figure 1: Average stress-strain curves of all groups.

\subsection{Brick masonry columns with double/triple layer of ferrocement (groups E and F)}

The specimen of groups $\mathrm{E}$ and $\mathrm{F}$ treated with ferrocement having 2 and 3 layers respectively of wire meshes did not give results better than group D having one layer of ferrocement. The ultimate loads were $282 \mathrm{kN}$ and $294 \mathrm{kN}$ respectively for 2 and 3 layers of ferrocement, an increase of about $100 \%$ in the load carrying capacity of columns as compared to $158 \%$ increase due to a single layer of ferrocement application. The absence of higher contribution by ferrocement with more meshes was due to budging and early bond failure between the mesh layers and smaller size of top and bottom steel plates $(255 \mathrm{~mm})$ than the over all cross section of the samples having multi-layers of wire meshes. The stress-strain curve is shown in Figures 1 and 2. 


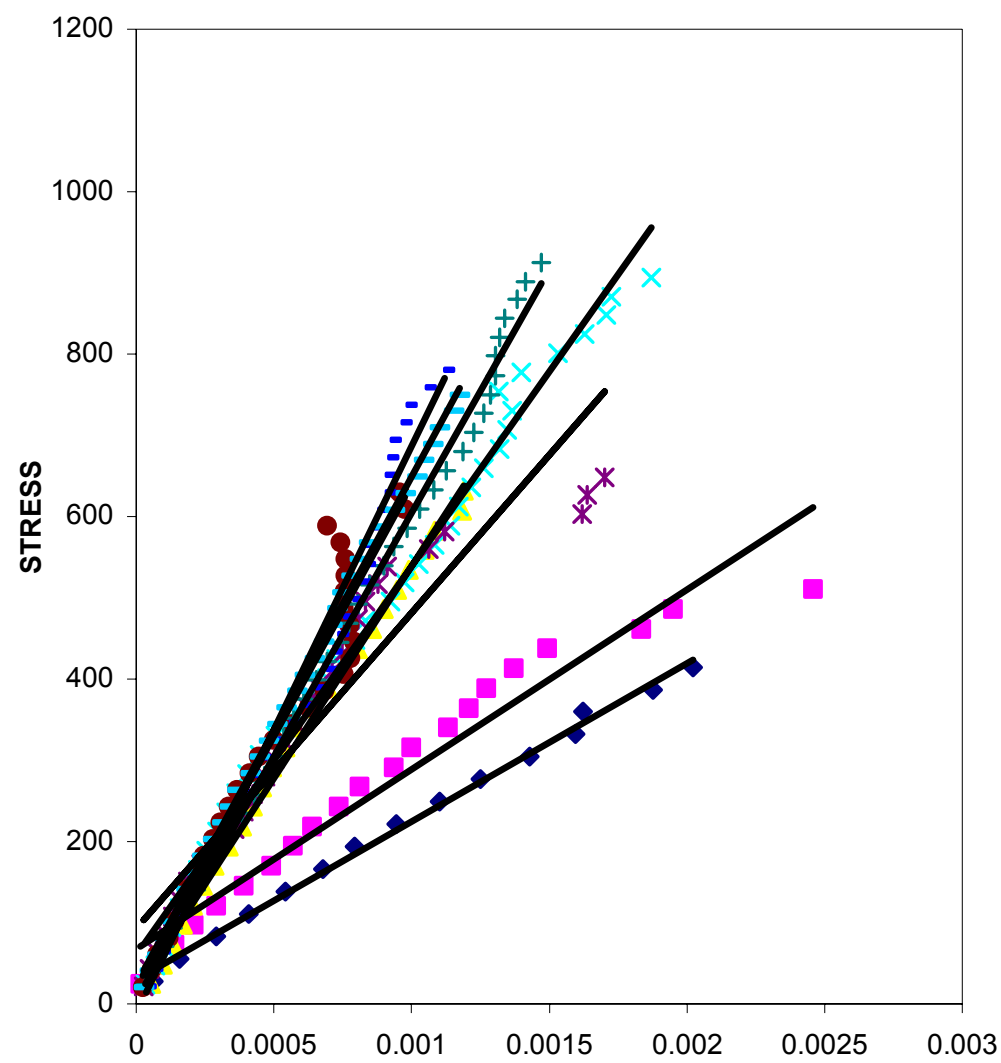

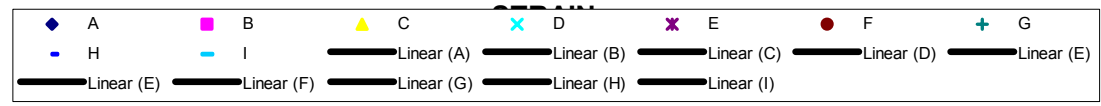

Figure 2: $\quad$ Trend line - stress-strain curves.

\subsection{Brick masonry columns with single layer of ferrocement and bonding chemical applied (group G)}

In the course of samples preparation of this group, a bonding agent, Sika-Latex was used in addition to nailing the mesh layer. The average failure load $376 \mathrm{kN}$ of this group although significantly higher i.e. $164 \%$ than the control specimen, did not show much improvement over its corresponding group D of samples having one layer of mesh nailed to the core, without any bonding agent. However, the Sika-Latex bonding was effective in controlling the spalling of outer mortar layer on failure. The failure strains were almost $10 \%$ lower than the specimen with single layer of ferrocement without any bonding agent. The propagation of cracks upto failure was gradual. 


\subsection{Brick masonry columns with double/triple layer of ferrocement and bonding chemical applied (groups $\mathbf{H}$ and $\mathbf{I}$ )}

The columns with $2 / 3$ layers of ferrocement application failed at $300 \mathrm{kN}$ and $306 \mathrm{kN}$ respectively showing $111 \%$ and $116 \%$ strength improvements over the control specimen. The specimen of these groups did not show much improved results over similar groups $\mathrm{E}$ and $\mathrm{F}$ specimen having same number of meshes but without application of bonding agent. Sika-Latex agent was not effective in maintaining bond between the mesh layers. The stress-strain diagrams are shown in Figures 1 and 2.

\subsection{Permeability testing on ferrocement specimen}

The capillary rise test indicated that ferrocement used was watertight. The w/c ratio of ferrocement mortar used was 0.3 which theoretically should also be watertight. Same results were confirmed by ISAT. Due to impermeability of ferrocement, it is expected to be highly durable in offensive environments. Weight recordings on $50 \mathrm{~mm}$ cubes kept in water for 30 days indicated constant weight before and after the soaking period indicating the ferrocement was watertight and impermeable.

\section{Discussion of results}

From the summary of these results it can be clearly observed that the load carrying capacity of ferrocement encased brick masonry columns increased significantly. It is evident that a significant increase in failure load capacity can be achieved using only one layer of ferrocement. Failure strains were observed to be reduced by about $50 \%$ on application of single layer of ferrocement. Additional layers ( 2 or 3 ) of ferrocement did not contribute much due to bond failure between them and while bulging outwards these layers pulled the inner mesh along and thus affecting the results. The contribution of Sika-Latex bonding agent was not much except for controlling the spalling of mortar at failure. The permeability of ferrocement layer is negligibly low thereby increasing the durability of the ferrocement applied columns.

It has been observed that ferrocement containing blended cements has performed even better than ferrocement with ordinary Portland cement on comparing results of recent studies. Strength improvement of about $30 \%$ along with complete watertightness in ferrocement with blended cement have been observed. The results of this study have been highly encouraging and use of ferrocement, with blended cement containing $25 \%$ rice husk ash, for repair and rehabilitation/strengthening of brick masonry columns has been recommended for practical use in the field. Use of rice husk ash for blending with ordinary Portland cement produces a stronger and durable material in addition to ease of in-situ application, reducing the disposal problem of this agricultural waste and reducing the costs of repairs. 


\section{Conclusions}

From the above study the following conclusions are drawn:-

- $\quad$ The ferrocement (using blended cement) treatment enhances the load carrying capacity of brick masonry columns by as much as $150 \%$ to $160 \%$. This increase can be economically achieved with one layer of wire mesh used in ferrocement nailed to core and with or without application of any chemical bonding agent. There were almost $50 \%$ reduction in strains at failure and much improved modulus was observed.

- $\quad$ Ferro cement having 2 and 3 layers of wire meshes are uneconomical and did not appreciably improve the load carrying capacity as noted in this experimental study.

- The initial resistance to cracking and thereafter crack growth mechanism of brick masonry columns improved quite significantly due to ferrocement treatment.

- The permeability of ferrocement layer is negligibly low thereby increasing the durability of the ferrocement applied columns.

\section{References}

[1] Kibriya. T., Crushed burnt clay bricks as aggregates for histrength concrete, Proceedings of McMat 2005, Joint ASCE/ASME/SES Conference on Mechanics and Materials, Baton Rouge, Louisiana, USA, 2005.

[2] Kibriya, T., Properties of Concrete with crushed brick aggregates, Dissertation submitted for partial fulfillment of Ph.D requirement, City University, London, U.K. 1991.

[3] Kibriya, T. and Speare, P.R.S., The use of crushed brick coarse aggregates in concrete, International Congress on "Concrete in the Service of Mankind", Dundee, Scotland, pp 204 - 207, 1996.

[4] Kibriya. T., Durability of concrete with crushed bricks coarse aggregates, 8th Islamic Countries Conference on Statistical Sciences, University of Bahrain, Bahrain, pp 161 - 164, 2002.

[5] Kibriya. T. and Baig. N., High performance concrete with blended cements using agrowastes, Proceedings of McMat 2005, Joint ASCE/ASME/SES Conference on Mechanics and Materials, Baton Rouge, Louisiana, USA, 2005.

[6] Kibriya. T. and Khan. S., High performance concrete pavements using agrowaste blended cement, Proceedings of McMat 2005, Joint ASCE/ASME/SES Conference on Mechanics and Materials, Baton Rouge, Louisiana, USA, 2005.

[7] Kibriya. T. and Khan. S., Performance of ecologically friendly waste in high strength concrete, IV Regional Conference on Civil Engineering Technology, Joint ASCE/ESIE Conference, Cairo, Egypt, 2005.

[8] Kibriya. T. and Baig. N., Agricultural wastes in construction, Blended cements containing rice straw ash, IV Regional Conference on Civil 
Engineering Technology, Joint ASCE/ESIE Conference, Cairo, Egypt, 2005.

[9] Kibriya. T., Ferrocement as retrofit material for old structures, Proceedings of McMat 2005, Joint ASCE/ASME/SES Conference on Mechanics and Materials, Baton Rouge, Louisiana, USA, 2005.

[10] Kibriya. T., Ferrocement - An innovative material for rehabilitation/strengthening of brick masonry columns, IV Regional Conference on Civil Engineering Technology, Joint ASCE/ESIE Conference, Cairo, Egypt, 2005.

[11] Paul. B.K. and Pama. R.P., Ferrocement, 1989.

[12] ACI 549, Ferrocement, American Concrete Institute, 1988.

[13] National Academy of Sciences, Ferrocement - Application in Developing Countries, A report of an Adhoc Panel of the advisory Committee on technological innovation, BOSTID, Washington, D.C., 1973. 